\title{
The Girl with the Bush Knife: Women, Adventure and the Tropics in Age of Consent and Nim's Island
}

\author{
Allison Craven and Chris Mann \\ Department of Humanities, School of Arts and Social Sciences \\ James Cook University, Townsville, Australia
}

\begin{abstract}
Dr Chris Mann and Dr Allison Craven are both Senior Lecturers in the Department of Humanities at JCU, where Chris Mann teaches French and Cinema; and Allison Craven teaches English, Cinema and Communication. Both have interests in Australian cinema, and Allison Craven has an ongoing research project on film and cinema in Queensland.
\end{abstract}

Our paper broadly concerns the distinction of our cinematic heroines, Cora in Age of Consent (dir. Michael Powell 1969) and Nim of Nim's Island (d. Mark Levin and Jennifer Flackett, 2008), from the more typical 'bush women' of Australian cinema and literature. The figure of our title, the 'girl with the bush knife', is a kind of marine creature, vividly captured in Age of Consent beneath tropical waters, mermaid-like but arguably a modified mermaid, while Nim of Nim's Island is an androgynous child adventurer descended from a swag of male mariners, whose several accessories include a bush knife. Their appearances in films 40 years apart are as much the object of inquiry in this paper as the femininities they perform, in that these films also represent minor milestones in Australian cinema at points at which the film industry has undergone change. The contexts of these changes are somehow signified, we suggest, by the use of tropical locations and settings, and we are therefore drawing attention to the way these female characters are accompanied by the spectacle of the tropical place in its difference from the more mythologised bush and desert landscapes of Australian mise-en-scene. Indeed, both Age of Consent and Nim's Island use locations in Queensland to fictionalize settings that are either in or towards Queensland, and both adapt the well established symbology of Eden, paradise and epic journey, that are defined in studies of Queensland in film and television by Bruce Molloy (1990) and Albert Moran (2001). But whereas Molloy and Moran largely concentrate on films produced by Australian interests within the ambit of a local film industry, our films are both instances of films made by international interests, with a degree of local involvement and capital, on visitations to 'locations less used', namely North and Far North Queensland. 
We look first at Cora and how her marine activities on the Barrier Reef resemble those of some 'bush women' in landed settings of earlier Australian films, and observe how Cora also departs from these conventions under the influences of the tropical setting and of Michael Powell's oeuvre. In comparison, Nim is the heroine of a postmodern children's fantasy, in which the tropical setting frames a parody of adventure fiction that resounds on the production locations rather than the heroine.

\section{Colourful: Cora the Marine Fisher, a 'Bush Woman' on the Barrier Reef}

Let us consider first the young Australian woman of Australian feature films of the 1920s and 1930s as described by John Tulloch. He speaks of the 'bush woman' who works in the stockyard where she dominates the men (Tulloch, cited in Routt, p. 31). Routt, agreeing with him, says that "independent leading women are common in Australian films of these two decades" (31). For Routt, the "bush woman" seems a "specifically Australian variant, and the ability to dominate men in the stockyard and on the station is not, for example, a notable feature of many American westerns of the period" (31). An example of such a character is in Ken Hall's A Squatter's Daughter (1933); for the main woman character, Hall says:

We began looking for a girl who could be the daughter of a squatter. Naturally she had to be very attractive, used to animals and had to be able to ride a horse as if born to the saddle. (Hall, 76)

The heroine may be a squatter's daughter but she fights successfully and virtually unaided to save her inherited property. The tradition of the independent woman is also evident beyond the 1930s. Two examples are found in films made by Ealing studios in Australia after the Second World War - The Overlanders (1946) and Bitter Springs (1951): the blond heroine of The Overlanders is shown several times riding a horse at speed and is contrasted with her would-be romantic interest who falls off his horse and is trampled by a stampede which she succeeds in stopping. The blond heroine in Bitter Springs is more in control of her rifle than her brother: where her brother killed an Aborigine who was threatening the group, she shoots the spear out of the hand of another potential assailant.

A long period intervened between these films and Age of Consent, a period in which relatively few feature films were made in Australia, either by local or international interests. Like Age of Consent, The Overlanders and Bitter Springs resulted from visitations 
to Australia by international studios, but whereas these earlier films typify the colonial view of Australia as terra nullius, featuring vast, empty, desert and inhospitable landscapes, the setting of Age of Consent in tropical North Queensland on Dunk Island represented a departure from a norm that returned in similar subsequent ventures such as Nicholas Roeg's Walkabout (released in 1971) and Wake in Fright (d. Ted Kotcheff, 1971). Age of Consent, however, which was based on Norman Lindsay's 1938 novel set in Bateman's Bay, New South Wales, is somewhat credited with stimulating a reawakening in Australian cinema production, and the subsequent decade resulted in the upsurge in nationalist local film production that came to be known as the 'New Wave', distinguished mostly by a crop of period dramas that also featured highly aestheticised landscapes and views of colonial history, and which often, as Sue Dermody and Liz Jacka (1988) have suggested, featured strong women of the pioneer type (see also Rattigan 1991). Age of Consent is therefore comparable in terms of its heroine, Cora, played by Helen Mirren, and contrastable in terms of its settings in the tropics, and in its international genesis. Powell himself later referred to Age of Consent as a "Girl Friday" story, and commented that casting the lead role demanded someone who could play an "impatient virgin" and that the obvious choice of the day was Mirren (Powell 1992, 502).

Cora, who emerges initially from the sea in Age of Consent, and is rather like an amphibious mermaid, has qualities, however, that align her with the traditional 'bush woman' style heroine if it is considered that no one else works the marine environment: the men, if they venture on to the water stay in a boat (except for one aggressive suitor whom Cora expels from the boat and half-drowns). Cora's domain is the waters of the Great Barrier Reef where she swims underwater with a spear. She harvests crayfish, prawns and oysters. The relationship of Cora to the reef is one of dominance and exploitation rather than of harmonious blending. In this, also, she is closer to the traditional bush woman. While Cora has been seen as an "apple-munching nature girl" who signifies an "affinity" between nature and "the feminine" (Meaghan Morris qtd in Murray 2009), which suggests some "wild child" (Cashill 2009) who plays with dolphins, she is no mermaid. The women encountered above rode horses with a saddle and farmed livestock and Cora with her spear and marine catch is like them.[i]

Norman Lindsay's Cora has a side which contrasts with this fisher Cora and which shows that a relationship with nature can be more harmonious. It occurs not in the water, where 
Lindsay's Cora fishes too, but on land where she has the gift of being able to remain almost invisible if she wishes:

the sun had given that young creature a protective colouring which absorbed her into the background, and assisted her remarkable powers of ceasing to be at a glance from Bradly. Her tawny mop of hair went light and dark in a flash, like the sheen of light on leaves; her brown limbs merged in the neutral tints of earth; her faded frock was any green-grey of the scrub. (41)

This Cora is closer to the depiction of Aborigines in Bitter Springs, which shows them as blending with the bush as they watch the arrival of the white settlers, or suddenly materialising from it when they have the settlers surrounded. In the film, Age of Consent, we rarely see Cora in the interior of the island, and when she is there, she is not blending with the landscape but stealing chickens or fighting with her grandmother. Cora's environment is mainly the beach, the foreshore and the sea, and her relationship to it is more that of the traditional dominant bush woman.

However, the aligning of Cora with the pattern of the traditional bush woman is not total. For a start, she is underwater, and the sea is an element that is more often viewed by Australians as dangerous and into which one immerses oneself at one's peril - white Australian stories of the sea are more concerned with shark attack than peaceful underwater fishing. While Cora's underwater activities are similar to those of the traditional bush heroine, she is not in the bush. In addition, her relationship with the water is multiple and somewhat contradictory: while she swims underwater with her spear, she is not in fact spearing fish - her catch, of oysters, prawns and crayfish, is gathered, not shot. One wonders what she is doing down there. This relationship is taken further from that of the hunter when she agrees to swim around underwater naked so that Bradley [sic][ii] can paint her. David Thomson (2003) sees in Powell's films "an unsettling mixture of emotional reticence and splurging fantasy", and thus "a mild beachcombing anecdote, is lit up by baroque passages of Helen Mirren, naked and underwater" (695). Her behaviour is unlikely, excessive, extravagant. Stafford (2010) speaks of "a striking juxtaposition of the human form against the natural beauty of the Great Barrier Reef" (our emphasis), and anyone with local knowledge of North Queensland waters would find improbable this naked body brushing past scratching coral branches. 
Powell's propensity for mingling realism with fantasy and the imagination (Hanson 2000, 782; and Thomson 2003, 695) has extended to his treatment of landscape in the past. For example, Black Narcissus (1947), which has what appear to be breath-taking views of the snowy upper slopes of Nanda Devi in the Himalayas or a precipitous cliff upon which a convent is perched, was shot entirely in a studio (Andrews and Kennedy 1979, 51). When one realizes this, one does indeed see the landscape of Black Narcissus as too fantastic to be possible: "The compositions are inexhaustibly eloquent" (51).[iii] It is clear from a statement with the credits at the start Age of Consent - "filmed on the Great Barrier Reef at Dunk Isle, North Queensland" - and from what Powell says in his autobiography[iv] that the parts of Age of Consent that show Dunk Island and the Great Barrier Reef were really filmed there, but Powell does play with the audience's perception of the authenticity of the setting: near the start of the film underwater shots of the Reef merge into the interior of a fish tank in New York reproducing a tiny section of the Reef as part of an advertisement for the durability of a Swiss watch. When one adds to this Cora's improbably naked presence the reef starts to bear a family resemblance to Powell's Himalayas. What Durgnat (1997) said of Powell and Pressburger is not inappropriately applied to Powell alone in Age of Consent: "They make the familiar strange, as naturally as breathing" (16).

Can one assume the bush woman of the films of the 1920s and 1930s was more realistically anchored in her surroundings? That is what Routt would encourage us to believe in speaking of "strong women characters" (31) and stockyards rather than for example melodramatic stereotypes set against intrusively staged backgrounds. It will be seen that the same question occurs when one considers another aspect of the unsettling of the image of the sensible bush woman dealing with her environment in Age of Consent by the film's use of colour with Cora. It is rather hard to be envisaging what would have been the Technicolor world which films of the 1920s and 1930s might have created and of which the bush woman would have been part. Charles Chauvel, who had his own inclinations towards the extravagant, might well have made more than one Jedda with orange cliffs, and one could suppose the raging inferno of a bush fire which closes The Squatter's Daughter would have been even more spectacular in colour. Nonetheless, the films in which the 'bush woman' is heroine are in black and white and give their heroines a sober air, however the filmmakers might have wished to colour them. 
Powell has a reputation as a lover of colour. Indeed, Powell's and Pressburger's most celebrated films emerged with the advent of Technicolour, and their cinematic adventurousness was in part to revel in the possibilities afforded by the colour medium. Statements made by critics about colour in the films - "Much has been written on the primacy of colour in Powell's films" (Bourne 2005); "Powell was an explorer, of locations, of color-spaces" (Durgnat 18) - are echoed by the titles of two of Powell's and Pressburger's best-known films, Black Narcissus and The Red Shoes, and by what is said within certain of the films themselves. In Black Narcissus, Sister Honey comments on what the young general was wearing in class that day: "Beautiful emeralds, the deepest and most beautiful green I've ever seen [...] his coat was the most wonderful pattern of pale violet stripes worked entirely in petit point". In Age of Consent, Bradley orders his paint over the phone: 'cadmium yellow, raw sienna, cobalt blue, ultramarine, yellow ochre, viridian, raw umber, burnt umber, indigo, [...], Prussian blue". In Age of Consent, this use of colour is often consistent with realistic expectations and so does not disrupt the picture of a bush woman. Cora has for example not been given the red hair which draws attention to the heroines of some of Powell's other films (Sister Clodagh in Black Narcissus before she became a nun, Vickie in The Red Shoes, Helen in Peeping Tom, Kay in They're a Weird $M o b$ ) designating them as elements in a colour composition. Cora is simply blond, like the bush heroines of The Overlanders and Bitter Springs, and her skin is bronzed, as one would expect. In both these respects she also is close to Norman Lindsay's Cora. Certainly, the colour of the setting is different from Lindsay's. Lindsay's setting is the south coast of New South Wales (157), and Lindsay's Bradly strives to capture effects of light and shade rather than colour - mangroves silhouetted against the light (43), or moving water on a grey day (178). On the other hand, while Powell has a love of vibrant colours, his choice of filming in the tropics means that in general his employing them does not create an unrealistic effect. Many of the colours Bradley orders in the list just quoted would be suitable for painting the sea and sky tones of the tropics, and many of the colour-scapes in which Cora is situated form a harmonious naturalistic whole.

But Powell does not only have the reputation of a lover of colour: his use of it can disrupt realism:

the use of color, which most critics cite as a trademark of the Powell-Pressburgerpartnership, is shaped into an expressionistic mode. Powell chose his hues from a broad visual palette, and 
brushed them onto the screen with a calculated extravagance that became integrated into the themes of the film as a whole. [...] [A critic has noted in The Red Shoes] the use of certain peculiarities of color, a criticism that has been magnified when some of Powell's and Pressburger's fantastic techniques occur in more realistic films. Their appearance in otherwise veracious contexts usually upsets normal audience expectations. (Hanson, 781-2) $[\mathrm{H}]$ is use of red: it was serene and personal, yet it was the cry "On guard!," absolutely certain that the imagination trounced reality (Thomson 1990, 27).

In Age of Consent, this disruption occurs in the use with Cora of colours that are not normally associated with nature, in particular strong pinks. In Norman Lindsay's novel 'her faded frock was any green-grey of the scrub'. (41) Moreover, although when he is assessing her pictorially, Lindsay's Bradly says, 'Nice bit of colour, that dress' (105), he does not specify the colour at that point - when painting Cora, he only designates the colour of her hair and her skin. Apart from one outing to the mainland wearing yellow, the Cora of the film wears a pink dress all the time when she is by or in the sea, except when she is naked. Moreover, she brings back from the mainland store a hot pink handbag which she conceals in the same cache as her savings. The 'appearance' of these colours in an otherwise 'veracious' colour context 'upsets normal audience expectations'. The pinks go rather well with her blond hair and the emerald sea, but are elements of an aesthetic composition rather than a realistic statement about Cora the reef fisher.

However, to paraphrase André Bazin (1970)[v], if one is to engage in making aesthetic statements, it is a good idea from the point of view of audience acceptance to give them some foundation in the reality provided by the plot line of the film. We have already noted above that Powell's choice of a tropical location allows his love of colour in general a free rein. For its part, his use of pink, particularly the strong pink of the handbag, suits a possible career change for Cora, which, however, is no less disruptive of her as a fisher bush woman - she is saving money because she wants to leave the reef to become a hairdresser in Brisbane. (It is never evident in Lindsay's novel what Cora is saving money for, but she doesn't mention hairdressing.) Cora's aspirations also bring her into comparison with the traditional 'bush woman'. Routt mentions Kate of On Our Selection as a quality 'bush woman' and Dad's pride, as someone who is "a model of what any parent would desire a child to be" (30) and sees her as an example of "the bush woman"”(31). Kate is in fact training to be a primary school teacher, but it is probably true for the majority of the bush women that their aim is not 
to leave the land. Despite her ability to take independent action, the bush woman has ties to the land through her membership of a family, and her aim is to perpetuate those ties. As Routt says, "Quite a number of Australian films made from 1919 to 1939 can be described as stressing family relationships" (30), and that of nearly 150 films that he viewed from the 1920s and 30s that father/daughter relationships were privileged in more than one third.

Just as Cora's career ambition can be seen as atypical of the bush woman, she also falls outside the pattern of family loyalty - she has no father or mother and is at odds with her exploitative grandmother whom she ends up unintentionally killing after wrestling with her to retrieve her savings. Not only is she not bound by emotional attachments as a daughter, for Cora the bush is part of what oppresses her. One may suppose that Cora is conforming to another Powell thematic: "Raging quietly at the heart of every Powell film is a battle between emotional contraries [...] between inhibition and free-spiritedness", even if this normally follows the course of a conflict between civilization as the oppressor and the "spontaneity" of "Nature" (Andrews and Kennedy 51). In short, while Cora does to a certain extent fit the pattern of the bush woman, she can diverge from it. While one might not fully agree with Combs's assessment of Cora - "she suggests, sprawled petulantly on her bed chewing at a plastic comb, [...] a combination of Lolita and the orphaned girl Ewie in Buñuel's The Young One" (Combs, 256) - it does seem as though Cora the bush woman would rather be in Brisbane than in the tropics. Cora's work, aspirations, and relationship to her environment all bear comparison to our second heroine, Nim, a child, and the way in which the spectacle of her heroism is adapted to the tropical place in which she dwells.

\section{Adventurous: Tropical Locations and the Girl on Nim's Island}

The narrative place in which Cora dwells is referred to in Age of Consent as

"Wantabadgeree" and the setting in Norman Lindsay's novel was Bateman's Bay, New South Wales. It is not clear precisely what led to the choice of North Queensland for the film locations although Michael Powell later regarded it as a kind of "fate" that brought him to Dunk Island (Powell 508, and see Endnote iv). Powell wrote that "Norman Lindsay's book had been a bit of a romp" but "my film belonged to the age of innocence" (508), so we might assume that Dunk Island provided an Eden-like setting and a sense of innocence. The crew may well have physically enjoyed their time on Dunk Island - "Mirren remembers the cast and crew [...] arrived barefoot [in Townsville] after three months filming on Dunk Island. 
[...] 'We'd gone completely native, the lot of us,' she says. 'We were all in our sarongs and blissed-out Dunk Island state [...]"” (qtd in Maddox 2005).

In Age of Consent, there are explicit references to "Queensland" and to "Brisbane", which is shown along with New York. Brisbane would have been an obscure destination to international audiences in 1969, while the colourful tropical settings also suggest a degree of Orientalism in the representation of Queensland and Queenslanders. Shades of the 'romp' are also evident in the low comedy elements that have been criticised from time to time (see, for instance, Bourne 2005), and, moreover, the stars of Age of Consent were non-Australians while the 'natives' were played by Australian performers, in minor roles. These aspects are of relevance in considering Nim's Island, which has resonances with Age of Consent in that both films represent adventurous international productions in North Queensland. The locations Powell utilized in pioneering fashion are now more frequently commodified for screen production and Nim's Island was produced in the more recent era of expansion of film production in Queensland (see Craven 2010).

Nim's Island, starring and produced by Jodie Foster, and based on the children's novel of the same name by Wendy Orr (2008), was one of two American films made in Far North Queensland in 2008, the other being Fool's Gold (Andy Tennant, 2008; see Craven 2010). Both films represent a recent era of Queensland's entry into the international runaway production industry encouraged through Queensland government initiatives, notably the former Pacific Film and Television Commission, now Screen Queensland, a body aimed at attracting and supporting film production in Queensland, especially through promotion of Queensland locations (see Craven 2010). The presentation of Queensland on the Screen Queensland website[vi] as an assortment of natural screen-worthy assets in the service of cultural production is suggestive of film production as a form of primary industry, and also goes to Nicholas Rothwell's (2007) observation that 'landscape', in its historical distinction from both 'wilderness' and 'town', is a construct that is intrinsically 'closer to culture than nature" yet is invoked as "emblem" of the "natural order".

The comparison of our heroines equally concerns the role of 'natural' settings in the cultural production of femininities. Nim (Abigail Breslin), the child adventurer of Nim's Island, by virtue of her age can barely qualify as a 'bush woman' even though she has some commonalities with the child of The Shiralee (d. George Ogilvie, 1987; and d. Leslie Norman, 1957[vii]), especially in attachment to her father, a characteristic of the bush woman 
of earlier. But, if Cora is a version of the 'quality bush woman' in a tropical setting, Nim collocates various masculine myths of the South Seas within the figure of a girl child, divulging her masculine literary antecedents as she dare-devils about her island with bush knife, spyglass and lizard (not parrot) on her shoulder. She is rover and castaway, islander and settler all in one. Like earlier male 'rovers' of imperial adventure fiction (see Pierce 1998; Bristow 1991), Nim is the off-spring of a seafarer father, Jack Rusoe (there are allusions to both Crusoe and Rousseau in his name), who is a marine biologist in search of a species of nanoplankton which he eventually finds and names after Nim (Protozoa Nim). Nim and her father have sailed to Nim's Island via Patagonia, Singapore and the Cook Islands. By settling on the island and establishing Rusoe's scientific outpost, Nim's story borrows the centuries-old idea of the island as (social) laboratory, and myths of Robinson Crusoe surround Nim's high-tech solitude during her father's absences at sea. In comparison to Cora's economic relationship to the Reef, Nim's labours on her island are turned to maintaining the settlement, and doing research for her favourite author, Alex Rover, tasks at which Nim proves as resourceful as Crusoe and as faithful as Friday, and over which the forces of nature, especially the elements, exert influences to which she responds variously with mastery, compliance, submission and luck. For all her masculine prototypes, Nim's relationship to nature, especially her close association with animals, helps to disambiguate her femininity through conventions derived from folk tale, "where animal helpers feature persistently as guides or magical aids to protagonists" (Whitley 19), and from Disney, where animal helpers to heroines signify the "taming of wild nature" (Whitley 24). Nim's postmodern Robinsonade is therefore a pastiche of the bush woman, the rover, and other tropes from children's fiction (absent mothers, adventure escapades, talking-to-animals) and folklore (including seal legends, except that the aquatic mammal is a sea-lion, named 'Selkie', supplied by Seaworld on the Gold Coast.)

Within this production, a curious relation is suggested between the narrative place and the production locations that resonates with Age of Consent, and draws attention to the roving tendencies of international film production. 'Roving' is playfully ironised in Nim's Island through Alex Rover (Foster), an agoraphobic San Franciscan author, who journeys from the northern hemisphere to find Nim, and who eventually falls in love with Nim's father. Whereas Bradley's journey from New York brings him to his tropical homeland and discovery of Cora, Nim's (unnamed) Island is located only by map coordinates, and is reached by Rover via a series of stopovers, including Borneo, Raratonga, Tuvalu. While the 
names have authenticity, the places are orientalised (see Craven 2010). The narrative mystery of the location of Nim's Island, and Nim's incensed response to visitations by unwelcome tourists, also encode a perspective on the production locations, which were a combination of Hinchinbrook Island and studios on the Gold Coast, with the additional effect of an erupting volcano (as active volcanoes are not a land form that Queensland can naturally provide). In the shadow of the volcano, Nim assaults the tourists with lizards in catapults before she accidentally triggers the eruption, inadvertently unleashing the primordial and chaotic forces of nature, from which the tourists flee.

If, as Susan Narramore Maher (1998) says, "every Eden must have its serpent", then in Nim's Island it seems to be in the form of the grotesque Queenslanders[viii] that Nim repels. These caricatured Queenslanders are adaptations of the "Troppo Tourists" in Wendy Orr's novel, over whom Nim's heroism is comically asserted, and whereby the superiority of the child is imposed upon the adult world. The allusions to Queensland, however, seem to have been devised in production of the film (as these allusions do not appear in the novel), and Nim, the heroine, is not a Queenslander. This is comically emphasized when, in an ironised drama-offirst-contact, Nim meets a little boy who strays from the Troppo Tourists, and Nim is persuaded that he is no threat when he explains that he is from Brisbane. The perspective that emerges towards the Queenslanders in Nim's Island is teasing, and arguably patronising, if it is considered that the local workforce are comically incorporated as intruders, in a manner that is also somehow reminiscent of the Australian performers in Age of Consent. The heroic child and her mastery of the production environment, however, distracted from these undertones, even in the marketing of the film as the heroism of Abigail Breslin's performance gained attention that was reinforced by the co-starring presence of Foster, herself a former child star.[ix]

Made almost 40 years apart, Age of Consent and Nim's Island both address the spectacle and desires of a female protagonist, in Age of Consent through the figure of the marine-fisher, Cora, in a film with mature themes that generated controversy about sex and nudity, while Nim 's Island is an unadulterated children's fantasy about an heroic little girl. Cora is emblematically associated with the forces of nature through her nude immersion in water and cagey play in shadows and trees. But armed with her coral knife, harvesting the waters for income, Cora is more bush woman than alluring mermaid as these qualities, we argue have affiliations with the young woman character frequently found in Australian feature films of 
the 1920s and 1930s, and sometimes later than that. In Nim's Island, on the other hand, we have drawn attention to the way Queensland tropical settings are deployed to 'naturalise' the heroism of the postmodern child, while also reflexively and covertly drawing attention to the context of production in Queensland even as the 'real' Queensland and its settler history are somewhat lampooned. The grounds of this comparison also include the stages in the history of film production in Australia at which these films have appeared: whereas Age of Consent represented the ending of a period in which visitations by international film-makers were more common but unusual in Queensland, the visitation model has returned in the case of Nim's Island in the current era of Queensland's supposedly more autonomous engagements in transnational film production. In each case, the girls with the bush knives - or such implements as are adapted in each case - have left cinematic footprints in the sands of these fatal tropical shores, tracing other pathways through the landscapes of Australian cinema.

\section{Works Cited}

Age of Consent. Dir. Michael Powell. Columbia Pictures. 1969. Sony Pictures Home Entertainment 2009.

Andrews, Nigel and Kennedy, Harlan. "Peerless Powell.” Film Comment 15.3 (May/June 1979): 49-55.

Bazin, André. "Poetic Realism." In Le Jour se lève. Jacques Prévert. Trans. Dinah Brooke and Nicola Hayden. London: Lorrimer Publishing, 1970: 5-12.

Bourne, Christopher. Age of Consent. Senses of Cinema. June 2005. http://archive.sensesofcinema.com/contents/cteq/05/36/age_of_consent.html Retrieve d 7 June 2009.

Bristow, Joseph. Empire Boys: Adventures in a Man's World. Ed Derek Longhurst. London: Harpercollins, 1991.

Cashill, Bob. "DVD Review: "The Films of Michael Powell” (A Matter of Life and Death and Age of Consent). 9 January 2009. http://popdose.com/dvd-review-the-films-of-michaelpowell-a-matter-of-life-and-death Retrieved 7 June 2009.

Combs, Richard. “Age of Consent.” Monthly Film Bulletin 36 (December 1969): 256. 
Craven, Allison. "Paradise Post-National: Landscape, Location and Senses of Place in Films Set in Queensland." Metro 166 (2010): 108-113.

Durgnat, Raymond. “The Powell and Pressburger Mystery.” Cineaste 23.2 (1997): 16-19.

Dermody, Susan and Jacka, Elizabeth. The Screening of Australia: Anatomy of a Film Industry. 2 Vols. Volume, 2. Sydney: Currency Press, 1988.

Hall, Ken G. Directed by Ken G. Hall: Autobiography of an Australian Film maker. Melbourne: Lansdowne Press, 1977.

Hanson, Stephen L. "Powell, Michael, and Emeric Pressburger." International Dictionary of Films and Filmmakers - 2: Directors. Ed. Tom Pendergast, et al. Detroit, New York, San Francisco, London, Boston, Woodbridge Ct: St. James Press 2000.

Lindsay, Norman. Age of Consent. North Ryde: CollinsAngus\&Robertson, 1991.

MacDonald, Kevin. Emeric Pressburger: The Life and Death of a Screenwriter. London and Boston: Faber and Faber, 1996.

Maddox, Garry. "Beyond the Age of Consent." Sydney Morning Herald. 11 June, 2005. www.smh.com.au/news/Film/Beyond-the-age-of-consent/2005/06/10/...

Retrieved 7 June 2009.

Molloy, Bruce. "Screensland: The Construction of Queensland in Feature Films." In Queensland Images in Film and Television. Eds. Jonathan Dawson and Bruce Molloy. U of Queensland P, 1990. Pp:

Moran, Albert. Queensland Screen: An Introduction. Brisbane: Griffith University, 2001.

Murray, Scott. "Michael Powell Down Under: Norman Lindsay's Age of Consent.” Senses of Cinema. 2009.

http://archive.sensesofcinema.com/contents/dvd/09/51/age-of-consent.html Retrieved 23/7/09. 
Naramore Maher, Susan. "Recasting Crusoe: Frederick Marrayat, R.M. Ballantyne, and the Nineteenth Century Robinsonade." Children's Literature Association Quarterly. 13.4 (1988): 169-75.

Nim's Island. Dir. Mark Levin and Jennifer Flackett. Walden Media. 2008.

Orr, Wendy. Nim's Island. Pictures by Kerry Millard. Crows Nest: Allen \& Unwin, 2008. (First published 1999).

Pierce, Peter. "The Adventure Novel and Imperial Romance." In The Encyclopaedia of the Novel. (2 Vols). Vol. 1 A-L. Ed. Paul Schellinger. Chicago and London: Fitzroy Dearborn, 1998. Pp 6-9.

Powell, Michael. Million-Dollar Movie. NY: Random House, 1992.

Rattigan, Neil. Images of Australia: 100 Films of the New Australian Cinema. Dallas: Southern Methodist University Press, 1991.

Rothwell, Nicholas. "Thea Astley Lecture 2007, Byron Bay Festival." etropic: electronic journal of studies in the tropics, Vol 6 (2007). http://www.jcu.edu.au/etropic

Routt, William D. "The Fairest Child of the Motherland: Colonialism and Family in Australian Films of the 1920s and 1930s." Chapter 2 in The Australian Screen. Albert Moran and Tom O'Regan eds. Harmondsworth: Penguin, 1989.

Stafford, Jeff. "Age of Consent." Turner Classic

Movies. 2010. http://www.tcm.com/tcmdb/title.jsp?stid=3772\&category=Articles

Retrieved 9 April, 2010.

Thomson, David. “Michael Powell 1905 - 1990.” Film Comment 26.3 (May 1990): 26-28.

----. The New Biographical Dictionary of Film. $4^{\text {th }}$ edn. London: Little, Brown. 2003.

Whitley, David. The Idea of Nature in Disney Animation. London: Ashgate, 2008. 
[i] Cora's 'wild' innocence also has been imbued retrospectively through Mirren's own recollections of herself in the role. Interviewed in 2005, she commented that not only was it her first movie, she had "hardly been on an aeroplane" and "never seen a palm tree" (Maddox 2005).

[ii] The Bradly Mudgett of Lindsay's novel becomes Bradley Morahan in Powell's film.

[iii] Powell's long-time collaborator, Emeric Pressburger, who was not involved in Age of Consent, is credited as the source of the projects, and furthermore, Black Narcissus takes its title from the novel from which it was adapted. Moreover, Kevin MacDonald (1996) writes that the "central theme" of Black Narcissus is the "impossibility of Europeans ever coming to terms with, let alone understanding, the sub-continent" (265).

[iv] According to Powell's autobiography (Powell 1992), the film was "90 percent made on the coast opposite Dunk Island and on the island itself' (507). The underwater scenes, he says, were staged and shot by Rod and Valerie Taylor, who took Helen Mirren out with them and she followed all their demands even though, he says, she admitted later to great fear (508). In Powell's words, he "discovered" Dunk Island (508) during a holiday in North Queensland during the filming of They're a Weird Mob, when he and some colleagues went to Cairns and sailed on the Reef and around the islands, including Dunk (475).

[v] Bazin is writing about the use of symbols in Marcel Carné's Le Jour se Lève (Daybreak):

Whether it be psychological (the personalities of Berry, Françoise and Clara) or material (the setting, cigarettes, wardrobe), the art of Carné and his colleagues is to make reality fulfil itself in terms of reality, before insinuating symbolic values. As if poetry only began to glow precisely when the action appears to be identified with the most life-like details. (12)

\section{[vi] See}

http://www.screenqueensland.com.au/pftc/shootInQLD/content.asp?pageid=36\&top=3

[vii] The Shiralee was another production by Ealing Studios, in 1957, that was shot partly in Australia, and starred Peter Finch. It was later re-made as an Australian television miniseries, starring Bryan Brown. 
[viii] See David Stratton's comments in At the Movies, broadcast 2 April 2008, ABC Television.

[ix] See, for instance, Foster's interview with Margaret Pomeranz (ABC Television, broadcast 2 April 2008), in which Foster comments on her mentoring of Breslin during the production of Nim's Island, and the experience and challenges it entailed for Breslin. 